M.V. Petlovanyi ${ }^{a}$, S.A. Zubko ${ }^{b}$, V.V. Popovych ${ }^{c}$, K.S. Sai ${ }^{a}$

\title{
PHYSICOCHEMICAL MECHANISM OF STRUCTURE FORMATION AND STRENGTHENING IN THE BACKFILL MASSIF WHEN FILLING UNDERGROUND CAVITIES
}

\author{
a Dnipro University of Technology, Dnipro, Ukraine \\ b PJSC «Zaporizhzhia Iron Ore Plant», Mala Bilozirka, Ukraine \\ ${ }^{c}$ Lviv State University of Life Safety, Lviv, Ukraine
}

\begin{abstract}
The strength and microstructural properties of the backfill massif have been studied and assessed when filling underground cavities that pose a threat of mine rocks collapsing in the process of mining mineral deposits. It is suggested that due to a tendency to mechanical destruction by crushing $\mathrm{Ca}-\mathrm{O}$ ionic bonds rather than $\mathrm{Si}-\mathrm{O}$ covalent ones, the backfill mixture composition is saturated with a large amount of $\mathrm{Ca}^{2+}$ ions. This leads to the formation of a highly-basic type of hydrated calcium silicates and a decrease in the massif strength properties. To study the mineral composition of the components of the mixture and solidified massif and to investigate the microstructure and chemical composition of new formations in the backfill massif, infrared spectroscopy and scanning electron microscopy were used. Laboratory studies of the strength properties of backfill massif were also conducted. The minerals of the mixture components, melilite and pseudowollastonite, have been revealed that perform the main function of the new formations occurrence. It was found that the strength of the backfill massif is by $16 \%$ less than the required standard value of $7.0 \mathrm{MPa}$ at the age of 90 days. It was determined that highly-basic jellylike hydrated silicates of tobermorite type of the group CSH (II) with variable composition and a ratio of $\mathrm{CaO} / \mathrm{SiO}_{2}=2-3$ are formed in the studied structure of the backfill massif after 90 days of hardening. There are no strong low-basic hydrated calcium silicate bonds that could have a reinforcing effect. Providing the conditions for occurrence of low-basic hydrated calcium silicates in the structure is one of the ways to create a hard backfill massif.
\end{abstract}

Keywords: backfill mixture; backfill massif; underground cavity; mineral composition; compressive strength; microstructure; hydrated calcium silicates.

DOI: $10.32434 / 0321-4095-2020-133-6-142-150$

\section{Introduction}

As a result of human engineering activity on the minerals extraction from the bowels by underground method, technogeneous cavities are formed that pose a threat of mine rocks collapse over time. In this regard, in the world mining practice, especially when mining various types of valuable ores, the field development technologies with subsequent filling of the mined-out space with solidifying backfill mixtures are widely used. This makes possible to prevent the earth's surface subsidence, improve mining operations safety and increase the mining completeness [1,2]. The solidifying backfill mixture is prepared in the surface stowing complex of the mines and is composed of a binding substance, an inert aggregate and water for mixing, which are mixed together by pipeline transport and fed into the underground mined-out space. Under the influence of physicochemical hydration process, the components interact with each other, and the backfill massif hardens and, eventually, becomes monolithic and hard. Typically, the great volumes of industrial waste from mining and smelting production, such as smelter slag, mine rocks, sands, churning stone, mine refuse, etc., are utilized in the composition of the backfill mixtures. They play a significant role in the formation of a monolithic massif $[3,4]$. 
In Ukraine, the mining technology with application of solidifying backfill mixtures is used at PJSC «Zaporizhzhia Iron Ore Plant», when extracting high-grade iron ore with an annual mixture production volume of 1.0 million $\mathrm{m}^{3}$, and at $\mathrm{SE}$ «Eastern Ore Dressing Complex», when mining uranium ore with a mixture production volume of 0.5 million $\mathrm{m}^{3}$ [5]. The quality and strength of the monolithic backfill massif formed in the underground cavities significantly affects such an important property as resistance to external loads. As a result of the impact of rock pressure and blasting operations during ore breaking, a monolithic backfill massif, like mine rock, is prone to destruction. In addition, its ingress into broken iron ore leads to its dilution and a significant decrease in the iron content $[6,7]$. When the backfill massif is destroyed, it is not always possible to identify the reason; however, the massif destruction is undoubtedly caused by the weakest chemical bonds, involved in the binding stone adhesion with an inert aggregate. These cases of backfill massif destruction and negative impact on the ore quality under the conditions of PJSC «Zaporizhzhia Iron Ore Plant» and other underground mines were reported in literature [8,9].

In the context of the indicated problematic aspects, the literature and information sources do not adequately cover the issues associated with the peculiarities of the formation backfill massif structure and strength, which is made of solidifying mixtures, as well as the assessment of its stability. There is no specific detailed information about ore deposits development when using solidifying backfill mixtures, where the structure of the backfill massif with the component mixture composition represented by ground slag, fluxing limestone and crushed rocks would be studied and tested under the conditions of PJSC «Zaporizhzhia Iron Ore Plant».

Therefore, in this work, the structural and strength properties of a cemented rock backfilling are investigated and assessed based on the results of physicochemical studies and laboratory tests of components and a solidified backfill massif.

\section{Materials and methods}

The study of the components and structure of the backfill massif as well as its strength properties assessment was conducted using the backfill mixture sample derived from PJSC «Zaporizhzhia Iron Ore Plant». The study was based on an integrated methodological approach, including a number of physicochemical methods and laboratory tests of backfill mixtures. To prepare the backfill mixture, a granular blast-furnace slag from PJSC «Zaporizhstal» was used as a binding material. The transported flux production waste and crushed rock refuse serve as inert aggregates, the warehouses being located near the stowing complex (Fig. 1).

To prepare the pulp, the slag was crushed in ball mills by wet grinding up to $55 \%$ of particles with a grain size of $0.074 \mathrm{~mm} \mathrm{[10].} \mathrm{In} \mathrm{the}$ technological process of filling underground minedout cavities, different variations of the backfill mixtures formulations were used; therefore, the proportion of components in $1 \mathrm{~m}^{3}$ of the mixture varied in the following ranges: granular blast-furnace slag $15-20 \%$, fluxing limestone $40-50 \%$, mine rock $20-30 \%$, and water $15-20 \%$.

The chemical composition of the used components of the backfill mixture according to the laboratory data of stowing complex is shown in Table 1.

To study the mineral composition of the backfill mixture components and identify their significance in the hydration process, the subsamples of slag, undersized flux and mine rocks were taken from the warehouses and the dump, and then tested by infrared spectroscopy according to generally accepted methodology [11]. Infrared spectra of samples with a grain size of slag and flux of $0.074 \mathrm{~mm}$ and a rock

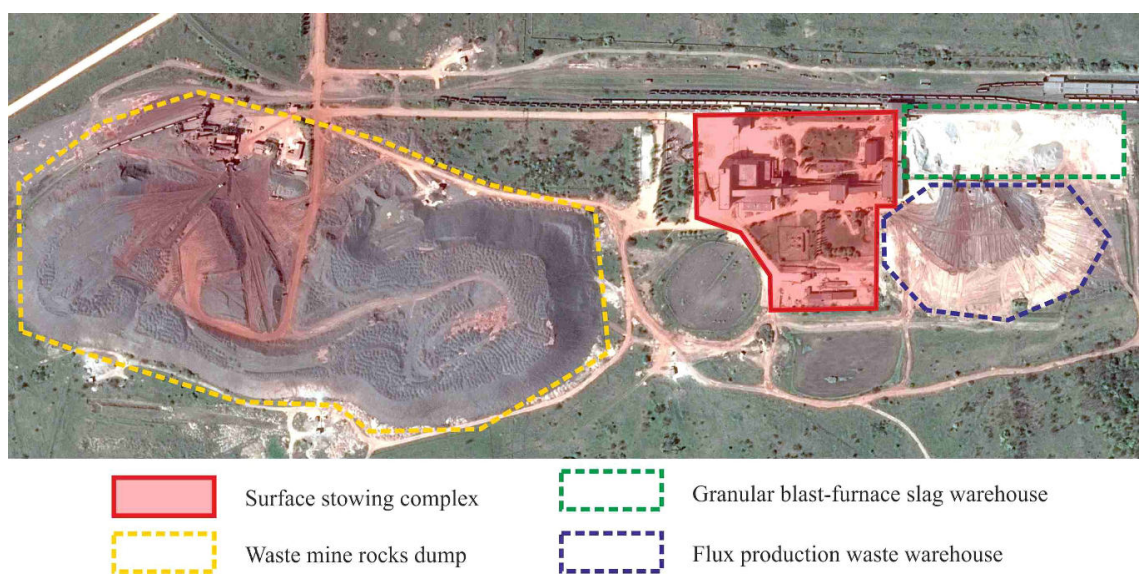

Fig. 1. The backfill mixture components disposition at PJSC «Zaporizhzhia Iron Ore Plant» 
Table 1

Chemical composition of the backfill mixture components

\begin{tabular}{l|c|c|c|c|c|c|c}
\hline \multirow{2}{*}{\multicolumn{1}{c|}{ Component }} & \multicolumn{9}{c}{ Content, \% } \\
\cline { 2 - 9 } & $\mathrm{SiO}_{2}$ & $\mathrm{Al}_{2} \mathrm{O}_{3}$ & $\mathrm{CaO}$ & $\mathrm{MgO}$ & $\mathrm{FeO}$ & $\mathrm{TiO}$ & $\mathrm{MnO}$ \\
\hline Granular blast-furnace slag & $37.8-39.5$ & $6.3-7.7$ & $47.4-49.4$ & $3.75-5.1$ & - & - & $0.68-1.2$ \\
\hline Flux production waste & 4.56 & 1.16 & 51.66 & 1.97 & 0.27 & - & - \\
\hline Crushed rock refuse & 55.42 & 8.12 & 0.90 & 6.84 & 25.70 & 0.12 & 1.60 \\
\hline
\end{tabular}

of $0.063 \mathrm{~mm}$ were registered by using a SPECORD75IR spectrometer. The spectra of the samples were obtained in the wavelength range of $4200-400 \mathrm{~cm}^{-1}$. The recorded spectra were identified in accordance with the reference data on the intensity shown by different minerals at specific wavelengths.

To study the structural strength characteristics of the backfill massif, the basic properties of the experimental backfill mixtures were determined under the laboratory conditions. The kinetics of hardening of the backfill massif was monitored at the age of 30,90 , and 180 days with the following composition of a mixture: granular blast-furnace slag $18 \%$, fluxing limestone $45 \%$, mine rock $20 \%$, water $17 \%$. Granular blast-furnace slag was crushed in a laboratory ball mill with a feeding of $1 \mathrm{~kg}$; this allowed achieving a grain size of $0.074 \mathrm{~mm}$ for not less than $55 \%$ of all particles. The backfill mixture was prepared for a 12-liter tank, sufficient for pouring-in and testing nine cubes-samples: three for each period of hardening, taking into account that the coefficient of strength values variation should not exceed $20 \%$. Initially crushed mine rock was added to the tank, then the flux wastes with blast furnace slag were mixed and dried, and then the dry mixture was tempered with water and mixed for 10 minutes. After mixing, the backfill mixture was tested for flow characteristics and yield strength, and then it was poured into metal molds $(10 \times 10 \times 10 \mathrm{~cm})$. When the samples had been fastened and solidified, they were placed into wet sawdust to simulate a mine environment before testing for strength. At the end of the hardening period, the backfill samples were tested for uniaxial compression using the PSU-10 and PSU-125 hydraulic presses. The order of mixtures preparation and the backfill massif formation is shown in Fig. 2.

The morphology and quantitative composition of the cement stone of the backfill massif after uniaxial compression test were determined by the scanning electron microscopy. To this end, REMMA-102-02 electronic microscope equipped with a micro-analyzer was used. Using the results of energy-dispersive $\mathrm{X}$-ray analysis, the content of the most important oxides $\left(\mathrm{CaO}, \mathrm{SiO}_{2}, \mathrm{MgO}\right.$, and $\left.\mathrm{Al}_{2} \mathrm{O}_{3}\right)$

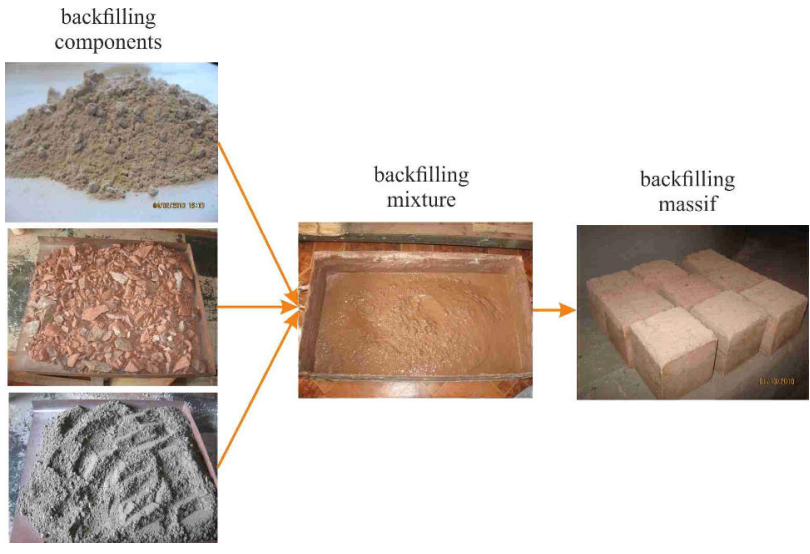

Fig. 2. The sequence of the backfill massif formation under laboratory conditions

was determined in the specimen of backfill massif fracture taken after uniaxial compression test (Fig. 3).

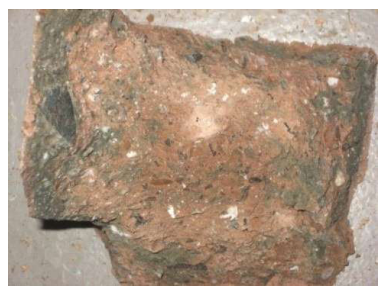

Fig. 3. The examined surface of a fracture specimen of the backfill massif

\section{Theoretical part}

Let us consider the peculiarities of possible crystalline new formations occurring in the backfill massif with a fineness of grinding of 55\% of particles with a grain size of $0.074 \mathrm{~mm}$. Under the influence of mechanical activation, granular slag minerals are able to exhibit binding properties during hydration process, but also the calcite contained in the undersized fluxing limestone also demonstrate poorly expressed binding properties. Fluxing limestone is supplied into the backfill mixture with a grain size of up to $5 \mathrm{~mm}$, while the amount of fine particles $(0.14 \mathrm{~mm})$ is minimal $(<5 \%)$. Without mechanical activation, the limestone is inert towards hydration, and this indicates the greatest importance of granular blast furnace slag minerals in the backfill mixture. 
Under the influence of mechanical activation, the destruction of structural bonds occurs in the slag minerals. Given the energy values of the most important bonds $\mathrm{Ca}-\mathrm{O}=1075.6 \mathrm{~kJ} \mathrm{~mol}^{-1}$ and $\mathrm{Si}-\mathrm{O}=1861 \mathrm{~kJ} \mathrm{~mol}^{-1}[12]$, it can be stated that $\mathrm{Ca}-\mathrm{O}$ ion bonds are exposed to the destruction to a considerably degree. In addition, a larger number of calcium $\mathrm{Ca}^{2+}$ ions, rather than $\mathrm{Si}^{4+}$ ones, will be formed on the surface of the ground slag particles. Due to hydration of melilite-like minerals, widespread slags components, a large number of jelly and colloidal solutions are formed, and the crystalline formations are mostly suppressed. It is believed that hydrated calcium silicates with the predominance of weak $\mathrm{Ca}-\mathrm{O}$ ionic bonds will be formed in the structure of the backfill massif during hydration process. This may explain a relatively low actual strength of the backfill massif, at which its destruction is observed. Such an important parameter as a basicity index of newly formed jellylike hydrated calcium silicates is predicted to be $\mathrm{CaO} / \mathrm{SiO}_{2} \geq 1.5$; that is, they will be highly-basic.

\section{Results and discussion}

Before laboratory testing of the backfill mixture preparation, the samples taken from the warehouses and the dump were studied by infrared spectroscopy. An infrared spectrum of granular blast furnace slag (Fig. 4) indicates the presence of melilite, as evidenced by absorption bands at $470 \mathrm{~cm}^{-1}$ (bond deformation vibrations of $\mathrm{Si}-\mathrm{O}-\mathrm{Si}$ ); and 858,950 , $980,1020 \mathrm{~cm}^{-1}$ (stretching vibrations of $\mathrm{Si}-\mathrm{O}$ in diorthogroups $\mathrm{Si}_{2} \mathrm{O}_{7}$ ). In addition, pseudowollastonite was detected by a series of peaks in the range of $420-500 \mathrm{~cm}^{-1}$ (bond deformation vibrations of $\mathrm{Si}-\mathrm{O}-\mathrm{Si}$ ); $570-580 \mathrm{~cm}^{-1}$ (stretching vibrations of $\mathrm{Ca}-\mathrm{O})$; a faint peak at $715 \mathrm{~cm}^{-1}$; and a series of peaks at $920-1110 \mathrm{~cm}^{-1}$ (stretching vibrations of $\mathrm{Si}-\mathrm{O}$ ).

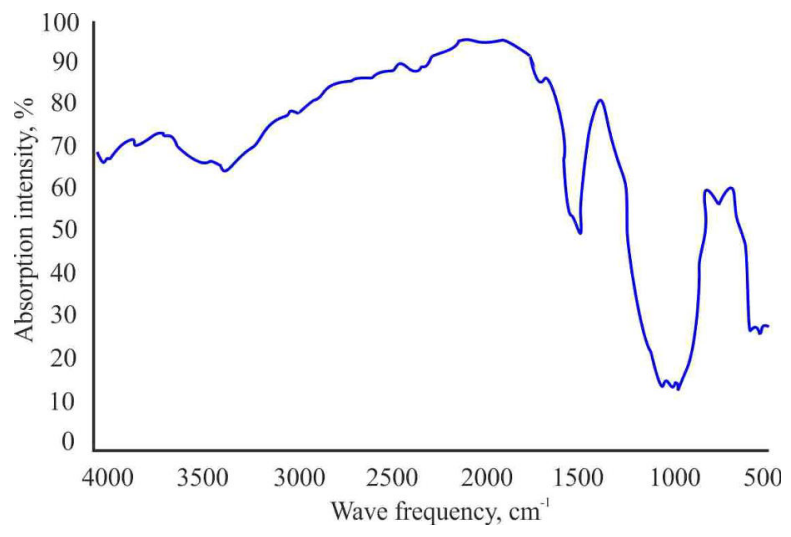

Fig. 4. Infrared spectrum of granular blast furnace slag
Fluxing limestone infrared spectrum (Fig. 5) reveals the presence of calcite in the sample, with clearly evidenced by absorption bands at 714,874 , 1418 and $1803 \mathrm{~cm}^{-1}$. The absorption bands at 725, 880, 1408 (the most intense band), 1440 , and $1825 \mathrm{~cm}^{-1}$ are associated with dolomite, which is typical of limestone carbonaceous rock. Carbonate spectra show a single peak (1400-1450 $\left.\mathrm{cm}^{-1}\right)$ corresponding to the stretching vibration of $\mathrm{CO}_{3}{ }^{2-}$ ions. To a lesser extent, wollastonite with weak absorption bands at $455,570,650,680 \mathrm{~cm}^{-1}$ and quartz with peaks at $465,520,590,700 \mathrm{~cm}^{-1}$ are also present.

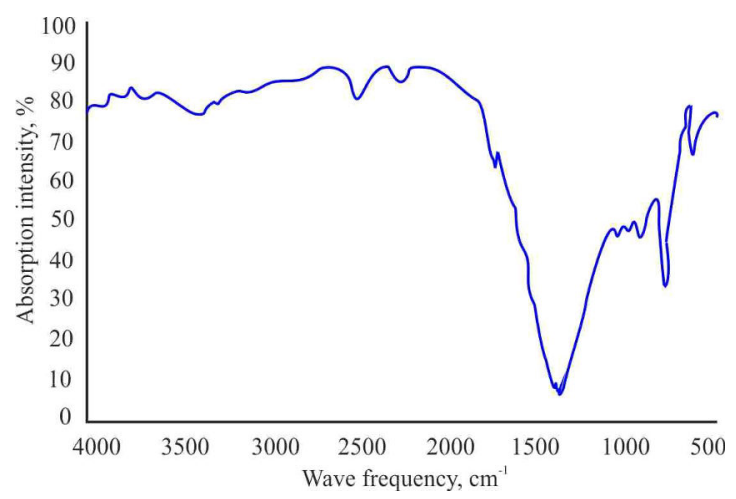

Fig. 5. Infrared spectrum of fluxing limestone

The infrared spectrum of dump rocks (Fig. 6), where the rocks resulting from underground mining works (shale, quartzite) are located, indicates the presence of hematite with weakly expressed absorption bands at $450-470$ and $530 \mathrm{~cm}^{-1}$, muscovite with absorption bands at 475-540; 750; $820 ; 920 ; 1030-1080$; and $3622 \mathrm{~cm}^{-1}$; biotite with absorption bands at $460 ; 620 ; 700 ; 1010 ; 1620$; and $3650 \mathrm{~cm}^{-1}$ and chlorite with absorption bands at 450; $670 ; 1010 ; 1450$; and $3600 \mathrm{~cm}^{-1}$. Occurrence of a series of peaks in the area of wavelengths of 3600 $\mathrm{cm}^{-1}$ indicates the presence of crystallization water in the structure of biotite, muscovite and chlorite.

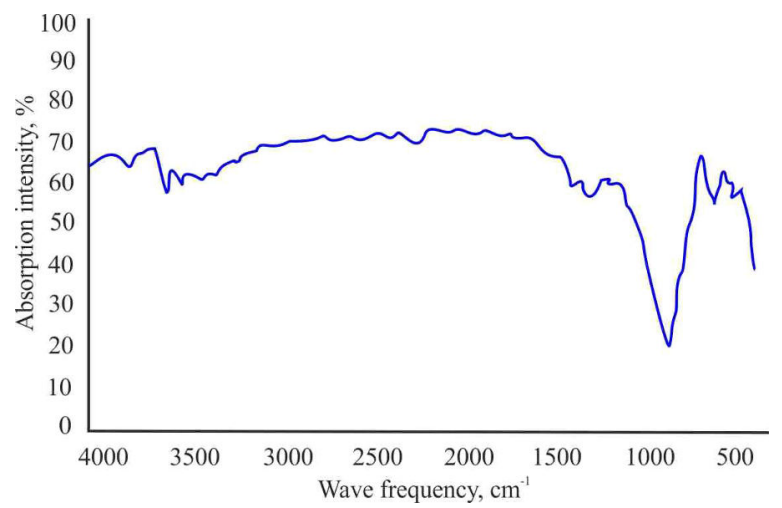

Fig. 6. Infrared spectrum of dump rocks 
Analysis of Figs. 4-6 reveals that all the minerals included in the composition of the backfill mixture components, sampled for the study, are inert except for melilite and pseudowollastonite.

Melilite, which is similar in composition to akermanite, is slowly hydrated and forms hillebrandite within 5 years. Pseudowollastonite is also exposed to slow hydration, forming a jellylike mass. Therefore, the blast furnace slag is exposed to grinding in ball mills during the backfill mixture preparation in order to excite the stronger binding properties. Melilite and pseudowollastonite play a key role in the occurrence of new formations of the hardened systems, and the remaining minerals form an inert base of the backfill massif, being the centers of new formations' growth during hydration process. Furthermore, the rocks containing hydromica (muscovite, sericite, and chlorite), that are constituents of mine rocks, are very poorly bound into cement stone.

The components selected in the warehouses and dump of the backfill mixture, which is used to fill underground cavities at the «Zaporizhzhia Iron Ore Plant», were tested under laboratory conditions for their rheological and strength properties. The parameters were in agreement with the conditions of pipeline transportation for the backfill mixture. Three samples of the backfill massif were tested at the age of 30, 90 and 180 days. The determined composition of backfill mixture and the results of the strength tests of the backfill mixture are presented in Tables 2 and 3, respectively, the variation coefficient of the results of determining the samples' strength being not exceed $11 \%$.

Table 2

\section{Compositional analysis of the backfill massif}

\begin{tabular}{l|c}
\hline \multicolumn{1}{c|}{ Component } & $\begin{array}{c}\text { Content of component of the } \\
\text { backfill mixture, } \%\end{array}$ \\
\hline Binding material: slag & 18 \\
\hline $\begin{array}{c}\text { Inert aggregate: limestone } \\
\text { rock }\end{array}$ & 45 \\
\cline { 2 - 2 } Water & 20 \\
\hline
\end{tabular}

Table 3

Changes in strength of backfill massif

\begin{tabular}{c|c|c|c}
\hline \multirow{2}{*}{ Age, days } & \multicolumn{3}{|c}{ Strength of backfill massif, MPa } \\
\cline { 2 - 4 } & Sample 1 & Sample 2 & Sample 3 \\
\hline 30 & 3.1 & 2.7 & 2.95 \\
\hline 90 & 6.2 & 5.6 & 5.9 \\
\hline 180 & 10.6 & 9.5 & 9.6 \\
\hline
\end{tabular}

Summarizing the data of the experimental values, one can establish the logarithmic dependence of the change in the strength of backfill massif on the time of hardening (Fig. 7). Over a period of 090 days, the backfill massif has gained the strength of 5.9 $\mathrm{MPa}$, then the changes become slight and the backfill massif has reached the strength of $9.9 \mathrm{MPa}$ over the period of $90-180$ days. Thus, the required strength of backfill massif is achieved after 90 days of hardening. Its strength should be not less than $7.0 \mathrm{MPa}$ for a mining depth of $640-740 \mathrm{~m}$, which is calculated considering the rock pressure effect.

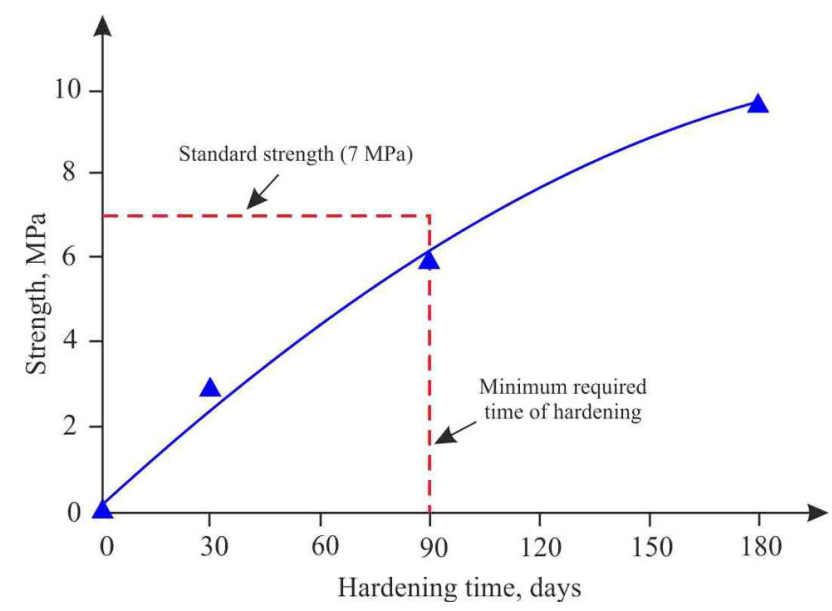

Fig. 7. Time dependence of change in the strength of backfill massif

According to the graph shown in Fig. 7, the backfill massif strength was $5.9 \mathrm{MPa}$ at the age of 90 days, which is by $1.1 \mathrm{MPa}$ (in other words, by $16 \%$ ) less than the required standard value (7.0 MPa). An insufficient strength of backfill massif under the influence of external loads can lead to the formation of fractures and subsequent inrushes. The tensile strength of backfill massif is of particular importance, which, like in concrete, is $5-10 \%$ of the compressive strength, since the precisely dangerous tensile stresses arise in certain areas of the backfill massif. To study the reasons for the insufficient strength of the considered backfill massif after a strength test, a fracture specimen of a backfill massif with a strength of $5.9 \mathrm{MPa}$ after 90 days of hardening was selected and tested by infrared spectroscopy and scanning electron microscopy. The infrared spectrum of the backfill massif sample is shown in Fig. 8. It exhibits a wide absorption band with a maximum at $3428 \mathrm{~cm}^{-1}$, that is caused by the vibration of $\mathrm{OH}$ group, a band in the region of stretching vibrations at $900-1100 \mathrm{~cm}^{-1}$, and bonds of $\mathrm{Ca}-\mathrm{O}$ at $520 \mathrm{~cm}^{-1}$. This may indicate the formation in the backfill massif structure of hydrated calcium silicates of tobermorite type. 


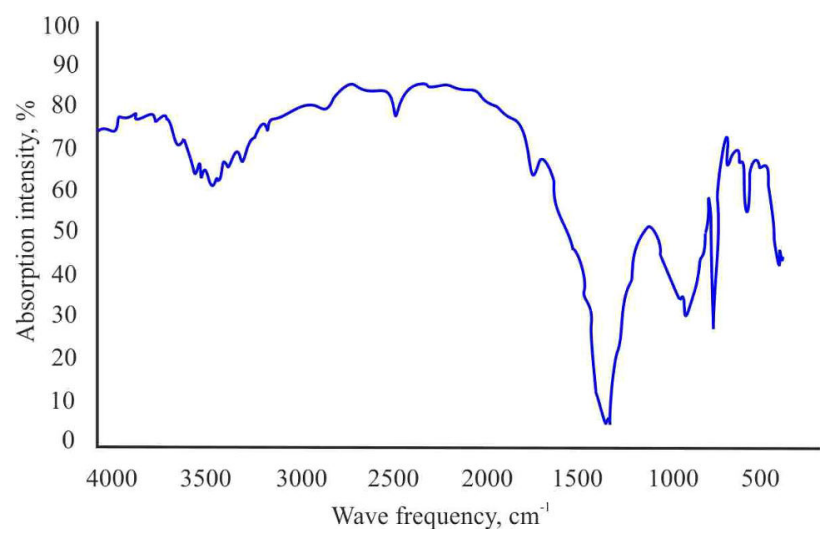

Fig. 8. Infrared spectrum of the backfill massif sample at the age of 90 days

A photograph of new structural formations in the backfill massif at the age of 90 days of hardening and the results of electron probe microanalysis are shown in Fig. 9. It can be seen that the studied new formations are located between two large aggregate particles, connecting them into a massif. The new formations are represented by hydrated calcium silicates, which are in a jellylike state and mainly show round shapes with single protruding disordered needles and plates; some interpore spaces are also present.

The structure formation of a cement stone with an intensive set of strength is accompanied by the occurrence of hydrated calcium silicates with needlefibrous thread-like intergrown particles as products of hydration process. However, Fig. 9 shows that these forms are almost absent in the structure of the backfill massif at the age of 90 days. Some centers of initial growth of needle-fibrous formations are observed only at point 3 .

The occurrence of new formations in the backfill massif obeys the features of the cement hydration process, where the ratio $\mathrm{CaO} / \mathrm{SiO}_{2}$ distribution plays a key role in structural bonds. When $\mathrm{CaO} / \mathrm{SiO}_{2} \geq 1.5$, the highly-basic jellylike hydrated calcium silicates are formed, while the low-basic ones with a needle-fibrous structure are formed if $\mathrm{CaO} / \mathrm{SiO}_{2} \leq 1.5$, which creates a reinforcing effect. The crystals of low-basic hydrated calcium silicates have the highest strength in the cement stone structure, while crystals of highly-basic hydrated calcium silicates have a tensile strength almost by 2 times less than that that of low-basic compounds crystals $[12,13]$.

An electron probe microanalysis of the selected points (Fig. 9, points 2, 3, 4 and 5) of the massif sample shows the chemical composition of newly formed hydrated calcium silicates with variable composition and a ratio $\mathrm{CaO} / \mathrm{SiO}_{2} \approx 2-3$, an average value being 2.63 . This indicates a high basicity index. Therefore, hydrated silicates of tobermorite type of $\mathrm{CSH}$ (II) group have been formed. The results obtained by electron probe microanalysis well correlate with theoretical assumptions about the formation of the backfill massif structure and strength. The occurrence of jellylike products in the cement stone structure was also reported in a number of published works; moreover, the elastic properties of the $\mathrm{CSH}$ jell are not changed significantly during 6 months of ageing $[14,15]$. This means that it is necessary either to mine ore on a contact with the backfill massif after 90 days of hardening or to strengthen the backfill massif structure. Therefore, the results of the conducted research show that one of the ways to create a hard backfill massif is to provide conditions for occurrence of low-basic hydrated calcium silicates with a basicity index $\mathrm{CaO} / \mathrm{SiO}_{2}$ tending to 1 at the age of up to 90 days. According to the measured contents of $\mathrm{CaO}$ and $\mathrm{SiO}_{2}$ in the backfill massif structure, the formed hydrated calcium silicates can be described by the
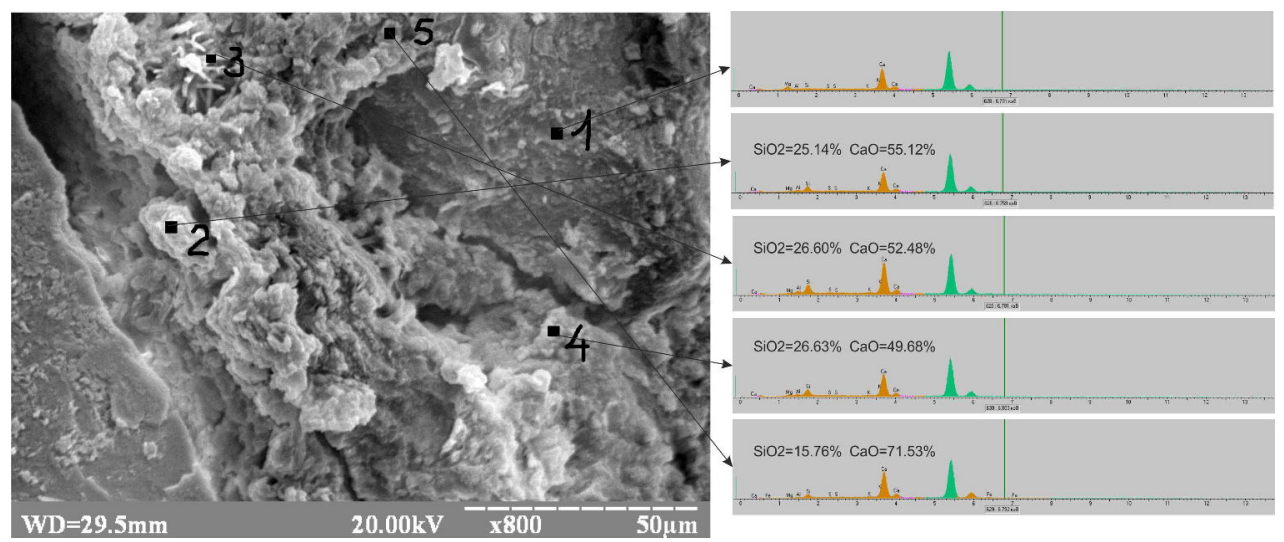

Fig. 9. Microstructure and chemical compositions of the backfill massif with the strength of $5.9 \mathrm{MPa}$ at the age of 90 days 
dollowing formula: $2.63 \mathrm{CaO} \cdot \mathrm{SiO}_{2} \cdot \mathrm{H}_{2} \mathrm{O}$.

Based on the formula, an important parameter, the content of structural water in hydrated calcium silicates, has been determined; it does not exceed $17 \%$. This confirms the fact that water largely performs the function of mixture transportation through the pipeline; hence, a part of it is absorbed by the backfill materials and the remaining water drains from the backfill massif during hardening process.

Summarizing the obtained results, one can suggest that the reasons for the decreased strength of backfill massif is the absence in its structure of strong bonds of low-basic hydrated calcium silicates at the age of 90 days; they are completely absent or will be formed much more later. This is especially important, because mining of ore should be started on a contact with this backfill massif after 3 months. It should also be noted than the backfill massif experiences external loads, such as rock pressure and seismic impact of blasting operations, when mining ore.

\section{Conclusions}

The microstructural and strength properties of the backfill massif were studied and assessed in this work based on the results physicochemical and laboratory tests of components and solidified cement stone. The following conclusions have been drawn:

- when grinding granular slag in mills of the stowing complex, predominantly ionic $\mathrm{Ca}-\mathrm{O}$ bonds are destroyed in the slag minerals structure, rather than covalent $\mathrm{Si}-\mathrm{O}$ bonds, as testified by its large binding energy. Thus, a higher amount of calcium $\mathrm{Ca}^{2+}$ ions rather than $\mathrm{Si}^{4+}$ ions is formed on the surface of the ground slag particles;

- infrared spectroscopy method revealed the formation of new minerals in the backfill mixture (melilite, pseudowollastonite, and calcite) during the hydration process. Because melilite and pseudowollastonite in the composition of slag are exposed to mechanical activation in ball mills, whereas calcite is not exposed, the binding properties of granular slag are developed. Melilite and pseudowollastonite play a key role in the hardening of the system, and the remaining minerals form an inert base of the backfill massif;

- it has been established a logarithmic dependence of a change in the strength of backfill massif on the duration of hardening. The backfill massif is formed from the backfill mixture with the following composition: granular blast-furnace slag $18 \%$, fluxing limestone $45 \%$, mine rock $20 \%$, and water $17 \%$. It has been found that the strength of the backfill massif is by $16 \%$ less than the required standard value of 7.0 MPa at the age of 90 days;

- highly-basic hydrated silicates of tobermorite type of the group CSH (II) are formed in the studied structure of the backfill massif after 90 days of hardening. There are no strong low-basic hydrated calcium silicate bonds with a reinforcing effect. The new formations consist of jellylike hydrated calcium silicates with round shape and with single protruding disordered needles and plates.

We think that one of the promising ways to create a hard backfill massif is to provide conditions for occurrence of hydrated calcium silicates with a basicity index $\mathrm{CaO} / \mathrm{SiO}_{2}$ tending to 1 . This can be achieved by introducing more $\mathrm{Si}^{4+}$ ions into the hydration process and decreasing the basicity index of newly formed hydrated calcium silicates.

\section{Acknowledgements}

The authors are grateful to the management of the stowing complex at PJSC «Zaporizhzhia Iron Ore Plant» for the opportunity to perform laboratory research and assistance. The results have been obtained in the framework and with the support of comprehensive implementation of Research and Development Projects No. 0119U000248 and 0120 U101099.

\section{REFERENCES}

1. An experimental study on compressive behaviour of cemented rockfill / Jiang H., Fall M., Li Y., Han J. // Constr. Build. Mater. - 2019. - Vol.213. - P.10-19.

2. An adaptive neuro fuzzy inference system to model the uniaxial compressive strength of cemented hydraulic backfill / Basarir H., Bin H., Fourie A., Karrech A., Elchalakani M. // Min. Miner. Depos. - 2018. - Vol.12. - No. 2. - P.1-12.

3. Review of man-made mineral formations accumulation and prospects of their developing in mining industrial regions in Ukraine / Petlovanyi M., Kuzmenko O., Lozynskyi V., Popovych V., Sai K., Saik P. // Min. Miner. Depos. - 2019. Vol.13. - No. 1. - P. 24-38.

4. Bini C., Maleci L., Wahsha M. Chapter 4 - Mine waste: assessment of environmental contamination and restoration // Assess. Restor. Reclam. Min. Infl. Soils. - 2017. - P.89-134.

5. Kuzmenko O., Petlyovanyy M., Heylo A. Application of fine-grained binding materials in technology of hardening backfill construction // Prog. Technol. Coal Coalbed Methane Ores Min. - 2014. - P.465-469.

6. The influence of geology and ore deposit occurrence conditions on dilution indicators of extracted reserves / Petlovanyi M., Lozynskyi V., Zubko S., Saik P., Sai K. // Rudarsko Geolosko Naftni Zbornik. - 2019. - Vol.34. - No. 1. - P.83-91.

7. Urli V., Esmaieli $K$. A stability-economic model for an open stope to prevent dilution using the ore-skin design // Int. J. 
Rock Mechan. Min. Sci. - 2016. - No. 82. - P.71-82.

8. Emad M.Z., Mitri H., Kelly C. Effect of blast-induced vibrations on fill failure in vertical block mining with delayed backfill // Can. Geotech. J. - 2014. - Vol.51. - No. 9. - P.975983.

9. Khomenko O., Kononenko M., Petlovanyi M. Analytical modeling of the backfill massif deformations around the chamber with mining depth increase // New Developments in Mining Engineering 2015: Theoretical and Practical Solutions of Mineral Resources Mining. - 2015. - P.265-269.

10. Petlovanyi M., Mamaikin O. Assessment of an expediency of binder material mechanical activation in cemented rockfill // ARPN J. Eng. Appl. Sci. - 2019. - Vol.14. - No. 20. - P.3492-3503.

11. Gorshkov V.S., Timashev V.V., Savel'ev V.G. Metody fiziko-khimicheskogo analiza vyazhushchikh veshchestv. - M.: Vysshaya Shkola, 1981. 335 p.

12. Butt Yu.M., Sychev M.M., Timashev V.V. Khimicheskaya tekhnologiya vyazhushchikh materialov. M.: Vysshaya Shkola, 1980. $472 \mathrm{p}$.

13. Teylor Kh. Khimiya tsementa. - M.: Mir, 1996. 560 p.

14. Determination of mechanical, flowability, and microstructural properties of cemented tailings backfill containing rice straw / Chen X., Shi X., Zhou J., Yu Z., Huang P. // Constr. Build. Mater. - 2020. - Vol.246. - Article No. 118520.

15. Insight into the evolution of the elastic properties of calcium-silicate-hydrate $(\mathrm{C}-\mathrm{S}-\mathrm{H})$ gel / Hu C., Ruan Y., Yao S., Wang F., He Y., Gao Y. // Cem. Concr. Compos. - 2019. Vol.104. - Article No. 103342.

Received 29.05.2020

\section{МЕХАНІЗМ ФОРМУВАННЯ СТРУКТУРИ I ЗМІЦНЕННЯ ЗАКЛАДНОГО МАСИВУ ПРИ ЗАПОВНЕННІ ПІДЗЕМНИХ ПУСТОТ}

\section{М.В. Петльований, С.А. Зубко, В.В. Попович, К.С. Сай}

Вивчені та оцінені міцнісні і мікроструктурні властивості закладного масиву для заповнення підземних пустот, які становлять небезпеку обвалення гірських порід у процесі розробки родовищ корисних копалин. Висунуто припушення, шо унаслідок більшої схильності до механічного руйнування шляхом подрібнення іонних зв'язків $\mathrm{Ca}-\mathrm{O}$, ніж ковалентних $\mathrm{Si}-\mathrm{O}$, відбувається насичення розчину закладної суміші великою кількістю іонів $\mathrm{Ca}^{2+}$, що призводить до формування високоосновного типу гідросилікатів кальцію і зниження міцності масиву. Для дослідження мінерального складу компонентів суміші та затверділого масиву застосовано метод інфрачервоної спектроскопії; для дослідження мікроструктури і хімічного складу кристалічних новоутворень в закладному масиві використано метод растрової електронної мікроскопії; здійснено лабораторні дослідження міцності закладного масиву. Виявлено мінерали компонентів суміші, що виконують ключову функцію формування кристалічних новоутворень - меліліт і псевдоволастоніт. Виз- начено, що у терміні 90 днів міцність закладного масиву на $16 \%$ менше від необхідного нормативного значення в 7,0 МПа. Виявлено, що в досліджуваній структурі закладного масиву через 90 днів твердіння утворюються високоосновні гелеподібні гідросилікати тоберморитоподібного типу групи CSH (II) змінного складу зі співвідношенням $\mathrm{CaO} / \mathrm{SiO}_{2}=2-3$, і відсутні міцні низькоосновні зв'язки гідросилікатів кальцію, що створюють армуючий ефект. Формування умов появи в його структурі низькоосновних гідросилікатів кальцію є одним із шляхів створення міцного закладного масиву.

Ключові слова: закладна суміш, закладний масив, підземні пустоти, мінеральний склад, міцність на стиск, мікроструктура, гідросилікати кальцію.

\section{PHYSICOCHEMICAL MECHANISM OF STRUCTURE FORMATION AND STRENGTHENING IN THE BACKFILL MASSIF WHEN FILLING UNDERGROUND CAVITIES}

M.V. Petlovanyi a, ", S.A. Zubko ${ }^{b}$, V.V. Popovych ${ }^{c}$, K.S. Sai ${ }^{a}$

a Dnipro University of Technology, Dnipro, Ukraine

b PJSC «Zaporizhzhia Iron Ore Plant», Mala Bilozirka, Ukraine

c Lviv State University of Life Safety, Lviv, Ukraine

* e-mail: petlyovany@ukr.net

The strength and microstructural properties of the backfill massif have been studied and assessed when filling underground cavities that pose a threat of mine rocks collapsing in the process of mining mineral deposits. It is suggested that due to a tendency to mechanical destruction by crushing $\mathrm{Ca}-\mathrm{O}$ ionic bonds rather than $\mathrm{Si}-\mathrm{O}$ covalent ones, the backfill mixture composition is saturated with a large amount of $\mathrm{Ca}^{2+}$ ions. This leads to the formation of a highly-basic type of hydrated calcium silicates and a decrease in the massif strength properties. To study the mineral composition of the components of the mixture and solidified massif and to investigate the microstructure and chemical composition of new formations in the backfill massif, infrared spectroscopy and scanning electron microscopy were used. Laboratory studies of the strength properties of backfill massif were also conducted. The minerals of the mixture components, melilite and pseudowollastonite, have been revealed that perform the main function of the new formations occurrence. It was found that the strength of the backfill massif is by $16 \%$ less than the required standard value of $7.0 \mathrm{MPa}$ at the age of 90 days. It was determined that highly-basic jellylike hydrated silicates of tobermorite type of the group CSH (II) with variable composition and a ratio of $\mathrm{CaO} / \mathrm{SiO}_{2}=2-3$ are formed in the studied structure of the backfill massif after 90 days of hardening. There are no strong low-basic hydrated calcium silicate bonds that could have a reinforcing effect. Providing the conditions for occurrence of low-basic hydrated calcium silicates in the structure is one of the ways to create a hard backfill massif.

Keywords: backfill mixture; backfill massif; underground cavity; mineral composition; compressive strength; microstructure; hydrated calcium silicates. 


\section{REFERENCES}

1. Jiang H., Fall M., Li Y., Han J. An experimental study on compressive behaviour of cemented rockfill. Construction and Building Materials, 2019, vol. 213, pp. 10-19.

2. Basarir H., Bin H., Fourie A., Karrech A., Elchalakani M. An adaptive neuro fuzzy inference system to model the uniaxial compressive strength of cemented hydraulic backfill. Mining of Mineral Deposits, 2018, vol. 12, no. 2, pp. 1-12.

3. Petlovanyi M., Kuzmenko O., Lozynskyi V., Popovych V., Sai K., Saik P. Review of man-made mineral formations accumulation and prospects of their developing in mining industrial regions in Ukraine. Mining of Mineral Deposits, 2019, vol. 13, no. 1 , pp. 24-38.

4. Bini C., Maleci L., Wahsha M. Chapter 4 - Mine waste: assessment of environmental contamination and restoration. In: Assessment, Restoration and Reclamation of Mining Influenced Soils, 2017, pp. 89-134.

5. Kuzmenko O., Petlyovanyy M., Heylo A. Application of fine-grained binding materials in technology of hardening backfill construction. In: Bondarenko, Kovalevs'ka, Ganushevych (eds.) Progressive Technologies of Coal, Coalbed Methane, and Ores Mining, 2014, pp. 465-469.

6. Petlovanyi M., Lozynskyi V., Zubko S., Saik P., Sai K. The influence of geology and ore deposit occurrence conditions on dilution indicators of extracted reserves. Rudarsko Geolosko Naftni Zbornik, 2019, vol. 34, no. 1, pp. 83-91.

7. Urli V., Esmaieli K. A stability-economic model for an open stope to prevent dilution using the ore-skin design. International Journal of Rock Mechanics and Mining Sciences, 2016, no. 82 , pp. $71-82$.
8. Emad M.Z., Mitri H., Kelly C. Effect of blast-induced vibrations on fill failure in vertical block mining with delayed backfill. Canadian Geotechnical Journal, 2014, vol. 51, no. 9, pp. 975-983.

9. Khomenko O., Kononenko M., Petlovanyi M. Analytical modeling of the backfill massif deformations around the chamber with mining depth increase. In: Pivnyak, Bondarenko, Kovalevska (eds.) New Developments in Mining Engineering 2015: Theoretical and Practical Solutions of Mineral Resources Mining, 2015, pp. 265-269.

10. Petlovanyi M., Mamaikin O. Assessment of an expediency of binder material mechanical activation in cemented rockfill. ARPN Journal of Engineering and Applied Sciences, 2019, vol. 14 , no. 20, pp. 3492-3503.

11. Gorshkov V.S., Timashev V.V., Savel'ev V.G., Metody fiziko-khimicheskogo analiza vyazhushchikh veshchestv [Methods of physico-chemical analysis of binder materials]. Vyshsaya Shkola Publishers, Moscow, 1981. 335 p. (in Russian).

12. Butt Yu.M., Sychev M.M., Timashev V.V., Khimicheskaya tekhnologiya vyazhushchikh materialov [Chemical technology of binder materials]. Vyshsaya Shkola Publishers, Moscow, 1980. 472 p. (in Russian).

13. Teylor Kh., Khimiya tsementa [Chemistry of cement]. Mir Publishers, Moscow, 1996. 560 p. (in Russian).

14. Chen X., Shi X., Zhou J., Yu Z., Huang P. Determination of mechanical, flowability, and microstructural properties of cemented tailings backfill containing rice straw. Construction and Building Materials, 2020, vol. 246, article no. 118520

15. Hu C., Ruan Y., Yao S., Wang F., He Y., Gao Y. Insight into the evolution of the elastic properties of calciumsilicate-hydrate (C-S-H) gel. Cement and Concrete Composites, 2019, vol. 104, article no. 103342. 